\title{
ZAKOŃCZENIE ADMINISTRACYJNEGO POSTĘPOWANIA EGZEKUCYJNEGO
}

\section{UWAGI WSTĘPNE}

Każde uregulowane przepisami prawa postępowanie, zarówno administracyjne, jak i sądowe, ma swój początek oraz koniec. Przepisy prawa procesowego, które wyznaczaja przebieg postępowania, zawierają na ogół ściśle określone warunki jego wszczęcia, zwane przesłankami procesowymi ${ }^{1}$ czy też przesłankami jego dopuszczalności ${ }^{2}$, jak i warunki, po spełnieniu których postępowanie ulega definitywnemu zakończeniu. Kres każdego postępowania powinien doprowadzić do realizacji wartości łączących się z osiagnięciem jego celu. Ogólnie rzecz ujmując, do wartości tych należy uzyskanie stanu pewności co do prawa, a tym samym stabilności obrotu prawnego przy jednoczesnym racjonalnym obciążeniu organów władzy publicznej w rozstrzyganiu sporów administracyjnych i sądowych ${ }^{3}$.

Administracyjne postępowanie egzekucyjne jest jednym z postępowań typu pozasądowego, które cechuje się wszakże wysokim poziomem szczegółowości regulacji prawnej - obejmuje podejmowane przez organ egzekucyjny i jego pracowników czynności zarówno o charakterze prawnym, jak i faktycznym ${ }^{4}$. Niewątpliwie także i ono ma swój początek, określony przepisami u.p.e.a. ${ }^{5}$ przebieg oraz kres. O ile jednak jego wszczęciu ustawodawca poświęcił sporo uwagi, formułując zarówno przesłanki zainicjowania tego procesu, jak i moment wszczęcia egzekucji administracyjnej, o tyle w u.p.e.a. nie ma wyraźnej regulacji, która odnosiłaby się do zakończenia postępowania egzekucyjnego.

${ }^{1}$ Z. Resich, Przestanki procesowe, Warszawa 1966, s. 57-58.

${ }^{2}$ L. Klat-Wertelecka, Niedopuszczalność egzekucji administracyjnej, Wrocław 2009, s. 110.

${ }^{3}$ Instytucją procesową, dzięki której realizowane są wymienione funkcje, jest prawomocność. Zob. M. Król, Teoretycznoprawna koncepcja prawomocności, Łódź 1992, s. 104-112; W. Piątek, Powaga rzeczy osqdzonej wyroku sqdu administracyjnego, Warszawa 2015, s. 143-144.

${ }^{4}$ Szerzej zob. P. Przybysz, Postepowanie egzekucyjne $w$ administracji. Komentarz, Warszawa 2011, s. 19-20; R. Hauser, Z. Leoński, w: R. Hauser, A. Skoczylas (red.), Postepowanie egzekucyjne $w$ administracji. Komentarz, Warszawa 2014, s. 8-9. Kazuistyczność przepisów tego postępowania jest także przedmiotem krytyki w doktrynie. Zob. W. Chróścielewski, w: idem, J. P. Tarno, Postepowanie administracyjne i postepowanie przed sqdami administracyjnymi, Warszawa 2011, s. 290-291.

${ }^{5}$ Ustawa z 17 czerwca 1966 r. o postępowaniu egzekucyjnym w administracji, t.jedn.: Dz. U. 2014, poz. 1619 ze zm. (dalej jako: u.p.e.a.). 
W doktrynie ${ }^{6}$ oraz orzecznictwie sądowym ${ }^{7}$ wskazuje się wprost, że postępowanie to kończy się wraz z wykonaniem przez zobowiązanego egzekwowanego obowiązu. Zdarzenie to nie znajduje jednak potwierdzenia w jakimkolwiek akcie procesowym stwierdzającym zgodność stanu faktycznego ze stanem pożądanym, który legł u podstaw wszczęcia postępowania egzekucyjnego. Powstaje wobec tego pytanie o powody braku regulacji ustawowej w tym zakresie oraz zasadność utrzymania takiego stanu prawnego w przyszłości.

Zrealizowanie celu egzekucji nie stanowi wszakże jedynego sposobu zakończenia postępowania egzekucyjnego. W praktyce postępowanie egzekucyjne w administracji może zakończyć się w różnoraki sposób, zarówno poprzez wykonanie obowiąku, jak i jego brak. Poza przymusowym zrealizowaniem obowiązku na wyróżnienie zasługuja przeszkody uniemożliwiające osiagnięcie podstawowego celu tego postępowania, skutkujące odmową przystapienia do egzekucji albo umorzeniem postępowania egzekucyjnego, które przybierają wszakże procesową formę postanowienia wydawanego przez organ egzekucyjny.

Celem niniejszego opracowania jest dokonanie analizy poszczególnych sposobów, w jakich może zakończyć się administracyjne postępowanie egzekucyjne i łączaccych się z tym problemów natury procesowej, na które zwracaja uwagę przedstawiciele doktryny. Punktem wyjścia będzie wyróżnienie dwóch odmiennych jego rezultatów w postaci realizacji dochodzonego obowiązku oraz braku jego wykonania. W trakcie rozważań podjęta zostanie próba zastanowienia się nad koniecznością wprowadzenia do u.p.e.a. wyraźnej regulacji procesowej zobowiązujacej organ egzekucyjny do wydania postanowienia o zakończeniu tego postępowania. Na wstępie warto zauważyć, że rozstrzygnięcie takie podejmowane jest przez komornika w sądowym postępowaniu egzekucyjnym na podstawie art. $816 \S 3$ k.p.c. ${ }^{8}$

\section{WYKONANIE EGZEKWOWANEGO OBOWIĄZKU}

\section{Całkowite wykonanie obowiązku}

Doprowadzenie do wykonania dochodzonego obowiązku jest podstawowym celem administracyjnego postępowania egzekucyjnego, któremu podporządkowane są wszystkie wysiłki całego zorganizowanego aparatu organów przymusu, o których stanowią przepisy u.p.e.a., na czele z organem egzekucyjnym. Działania tego rodzaju powinny być zawsze podejmowane zgodnie z ustalony-

${ }^{6}$ Z. Leoński, Administracyjne postępowanie egzekucyjne. Węzłowe problemy, Poznań 2003, s. 96; L. Klat-Wertelecka, Umorzenie administracyjnego postepowania egzekucyjnego, w: red. J. Niczyporuk, S. Fundowicz, J. Radwanowicz, System egzekucji administracyjnej, Warszawa 2004, s. 287; M. Masternak, w: T. Jędrzejewski, M. Masternak, P. Rączka, Administracyjne postepowanie egzekucyjne, Toruń 2013, s. 113-114.

${ }^{7}$ Wyrok NSA z 27 czerwca 2013 r., II FSK 2269/11, CBOSA; wyrok WSA w Białymstoku z 16 czerwca 2014 r., I SA/Bk 212/14, CBOSA.

${ }^{8}$ Ustawa z 17 listopada 1964 r. - Kodeks postępowania cywilnego, t.jedn.: Dz. U. 2014, poz. 101 ze zm. (dalej jako: k.p.c.). 
mi w u.p.e.a. regułami przy jak najmniejszym stopniu uciążliwości dla zobowiązanego, który nie wykonując dobrowolnie nałożonego na niego obowiązku, powinien liczyć się z koniecznością wdrożenia w stosunku do niego środków przymusu państwowego.

Biorąc pod uwagę ingerencyjny charakter przepisów u.p.e.a., dobrowolne bądź przymusowe wykonanie obowiązku obliguje organ egzekucyjny do zaniechania podejmowania dalszych czynności egzekucyjnych. Jeżeli zrealizowany został cel egzekucji, to zgodnie z art. $7 \S 3$ u.p.e.a. stosowanie środka egzekucyjnego staje się niedopuszczalne. Przejawem wyrażonej w tym przepisie zasady niezbędności ${ }^{9}$ jest wynikający z art. $45 \S 1$ u.p.e.a. obowiązek organu egzekucyjnego i egzekutora odstapienia od czynności egzekucyjnych w razie przedstawienia przez zobowiązanego dowodów stwierdzających wykonanie obowiązu. Zarówno przymusowe, jak i dobrowolne wykonanie obowiązku po wszczęciu postępowania egzekucyjnego powoduje konieczność jego zakończenia. Jak jednak zauważono w doktrynie, samo odstapienie od czynności egzekucyjnych nie oznacza definitywnego zakończenia postępowania. W jego wyniku organ egzekucyjny obowiązany jest orzec, czy należy umorzyć postępowanie egzekucyjne, czy też tylko je zawiesićc ${ }^{10}$. Pojawia się jednak pytanie, jak powinien postapić organ egzekucyjny, gdy przedstawione przez zobowiąanego dowody stwierdzające wykonanie obowiązku już po wszczęciu postępowania egzekucyjnego nie daja podstaw do umorzenia tego postępowania.

Jak zostało to już zauważone na wstępie, zakończenie postępowania egzekucyjnego na skutek całkowitego wykonania obowiązku nie zostało połączone z wydaniem przez organ egzekucyjny jakiegokolwiek aktu, który z procesowego punktu widzenia kończyłby to postępowanie. Ustawa p.e.a. o jego zakończeniu stanowi w art. 64c $\S 8$ i $§ 12$ u.p.e.a. w kontekście kosztów egzekucyjnych, które w odniesieniu do opłat powstaja z mocy prawa na skutek podejmowanych przez organ egzekucyjny czynności procesowych. Sposób poboru oraz obliczenia wysokości kosztów określony został wprost w u.p.e.a. W przypadku zakończenia postępowania egzekucyjnego wskutek wyegzekwowania wykonania obowiązku, zobowiązany w terminie $14 \mathrm{dni}$ od dnia powiadomienia o wysokości pobranych kosztów egzekucyjnych może złożyć wniosek o wydanie postanowienia w przedmiocie tych kosztów. W nieobowiąującym już stanie prawnym data zakończenia postępowania egzekucyjnego była odnotowywana na wzorach tytułów wykonawczych ${ }^{11}$. Aktualnie przyjęte wzory nie przewiduja konieczności podania takiej informacji ${ }^{12}$.

${ }^{9}$ Szerzej zob. A. Skoczylas w: R. Hauser, Z. Niewiadomski, A. Wróbel (red.), System prawa administracyjnego, t. 9: Prawo procesowe administracyjne, Warszawa 2010, s. 403-404.

10 J. P. Tarno, Gwarancje procesowe służace zobowiazanemu w egzekucji administracyjnej, „Przegląd Podatkowy” 2009, z. 7, s. 13.

${ }^{11}$ Wzory tytułów wykonawczych zostały określone w załącznikach do rozporządzenia Ministra Finansów z 22 listopada 2001 r. w sprawie wykonania niektórych przepisów ustawy o postępowaniu egzekucyjnym w administracji, Dz. U. 2001, Nr 137, poz. 1541 ze zm. Wszystkie zawierały rubryki zatytułowane „zakończenie egzekucji”.

${ }_{12}$ Aktualnie wzory tytułów wykonawczych zostały określone w załącznikach do rozporządzenia Ministra Finansów z 16 maja 2014 r. w sprawie wzorów tytułów wykonawczych stosowanych w egzekucji administracyjnej, Dz. U. 2014, poz. 650. Nie mają one specjalnych rubryk, które odnosiłyby się do zakończenia egzekucji bądź postępowania egzekucyjnego. 
Należy wobec tego zastanowić się, dlaczego ustawodawca nie wprowadził osobnej regulacji procesowej dotyczącej zakończenia administracyjnego postępowania egzekucyjnego i czy wydanie takiego postanowienia przez organ egzekucyjny w sytuacji całkowitego wykonania obowiązku byłoby uzasadnione. Jak zostało to już zasygnalizowane na wstępie, postanowienie o takiej treści wydawane jest przez komornika sądowego na podstawie art. $816 \S 3$ k.p.c. $\mathrm{w}$ ramach cywilnego postępowania egzekucyjnego, jeżeli postępowanie egzekucyjne kończy się w każdy inny sposób aniżeli przez umorzenie ${ }^{13}$. W doktrynie postępowania cywilnego wskazuje się wobec tego, że obecnie postępowanie egzekucyjne w każdym przypadku powinno kończyć się zapadnięciem postanowienia albo o umorzeniu postępowania, albo o ukończeniu egzekucji ${ }^{14}$.

Wydanie postanowienia o zakończeniu administracyjnego postępowania egzekucyjnego byłoby niewątpliwie korzystne dla zobowiązanego, ponieważ uzyskiwałby on w ten sposób autorytatywne potwierdzenie wykonania egzekwowanego obowiązku. Zyskiwałby on także pewność, że nie toczy się już $\mathrm{w}$ stosunku do niego postępowanie egzekucyjne. Wydanie tego postanowienia z perspektywy zobowiązanego sprzyjałoby uzyskaniu stanu pewności co do prawa. Warto jednak zastanowić się, czy w obecnie obowiąującym stanie prawnym wartości te nie sa realizowane przez zastosowanie innych regulacji prawnych. Już bowiem z zasady niezbędności wywodzonej z art. 7 § 3 u.p.e.a. wynika niedopuszczalność stosowania środka egzekucyjnego, gdy egzekwowany obowiązek został wykonany albo stał się bezprzedmiotowy. Zasada ta znajduje wyraz w wielu szczegółowych przepisach u.p.e.a., w tym m.in. w art. 33 $\S 1$ pkt 1 u.p.e.a., art. 45 u.p.e.a. czy też art. $59 \S 1$ pkt 1 u.p.e.a. Zobowiazzany dysponuje więc $\mathrm{w}$ postępowaniu egzekucyjnym takimi środkami prawnymi, które pozwalaja jemu na szybkie zakończenie prowadzonego postępowania w przypadku, gdy obowiązek został już wykonany. Ponowne prowadzenie egzekucji w zakresie, w jakim obowiązek został już zrealizowany może być zwalczane przez zobowiązanego poprzez wniesienie powództwa przeciwegzekucyjnego, o którym stanowi art. $840 \S 1$ pkt 2 k.p.c. ${ }^{15}$ Oprócz tego stosownie do art. 168b u.p.e.a. zobowiązany może dochodzić odszkodowania od organu egzekucyjnego lub wierzyciela za wszelkie szkody wyrządzone wskutek niezgodnego z przepisami prawa wszczęcia lub prowadzenia egzekucji administracyjnej. Poza tym wydaje się, że nie ma powodów, które stałyby na przeszkodzie zwróceniu się przez zobowiązanego do organu egzekucyjnego lub do wierzyciela o wydanie zaświadczenia o niezaleganiu co do uiszczenia konkretnej należności pieniężnej czy też o wykonaniu danego obowiązku niepieniężnego.

$13 \S 3$ został dodany do art. 816 k.p.c. na podstawie art. 1 pkt 90 ustawy z 16 września 2011 r. o zmianie ustawy - Kodeks postępowania cywilnego oraz niektórych innych ustaw, Dz. U. 2011, poz. 233, poz. 1381. Przepis ten wszedł w życie 3 maja 2012 r. W uzasadnieniu projektu tej nowelizacji wyjaśniono, że jego wprowadzenie było związane z istniejącymi wątpliwościami co do sposobu orzekania o kosztach postępowania egzekucyjnego. Zob. http://orka.sejm.gov. pl/Druki6ka.nsf/wgdruku/4332 [dostęp: 16.09.2015]. Szerzej na ten temat zob. H. Pietrzkowski, w: T. Ereciński (red.), K.p.c. Komentarz, t. 4: Postepowanie egzekucyjne, Warszawa 2012, s. 216.

${ }_{14}$ O. Marcewicz, w: A. Jakubecki (red.), K.p.c. Komentarz, Warszawa 2015, s. 1141.

15 P. Ostojski, W. Piątek, Egzekucja administracyjna świadczeń pieniężnych, Wrocław 2014, s. 264 . 
W przypadku obowiązków nakładanych na podstawie o.p. ${ }^{16}$ podstawą do wydania tego dokumentu urzędowego są przepisy tej ustawy, a w każdym innym przypadku podstawą taką byłyby przepisy k.p.a. ${ }^{17}$ Wydaje się, że wydanie takiego zaświadczenia w skutkach prawnych odpowiadałoby deklaratoryjnemu w swojej istocie postanowieniu o zakończeniu postępowania egzekucyjnego. Najistotniejszym bowiem z punktu widzenia zobowiązanego elementem tego aktu byłoby potwierdzenie realizacji dochodzonego obowiązku.

Wydanie postanowienia o zakończeniu administracyjnego postępowania egzekucyjnego nie byłoby uzasadnione $\mathrm{z}$ innych jeszcze względów. Pozostawałoby ono w sprzeczności z samą istotą tego postępowania, które nakierowane jest przede wszystkim na wykonanie obowiąku. Wszelkie podejmowane w nim czynności procesowe służą osiagnięciu tego celu. W postępowaniu tym istotna rolę odgrywają czynności faktyczne podejmowane przez pracowników organu egzekucyjnego, które w bezpośredni sposób zmierzaja do wykonania obowiązku. Nałożenie na organ egzekucyjny powinności wydania postanowienia o zakończeniu postępowania egzekucyjnego prowadziłoby do niepotrzebnego sformalizowania ostatniego jego etapu już po zakończeniu egzekucji administracyjnej, nie przynosząc żadnych korzyści polegających na usprawnieniu jego biegu czy też zapewnieniu wyższego poziomu jego efektywności. Wprost przeciwnie, postanowienie takie mogłoby przyczynić się do niepotrzebnego skomplikowania biegu tego postępowania. Nietrudno wyobrazić sobie, że zobowiązani mogliby domagać się jego wydania, jeszcze zanim dochodzony obowiązek zostałby wyegzekwowany, składając przykładowo skargę na bezczynność organu egzekucyjnego do sądu administracyjnego po uprzednim wyczerpaniu istniejącego trybu zaskarżenia. Jeżeli postanowienie to byłoby zaskarżalne zażaleniem, to z mocy art. $3 \S 2$ pkt 3 p.p.s.a. ${ }^{18}$ przysługiwałaby na nie skarga do sądu administracyjnego. Kontrolą sądową objęty zostałby w ten sposób kolejny akt wydawany w postępowaniu egzekucyjnym, co nie sprzyjałoby ani zwiększeniu poziomu ochrony sądowej uczestników tego postępowania, ani nie byłoby uzasadnione z punktu widzenia racjonalnego obciążenia sądów administracyjnych kontrola postanowień zapadających w tym postępowaniu ${ }^{19}$. Niezależnie od tego zagadnieniem kontrowersyjnym pozostawałaby dopuszczalność wszczynania postępowań w jednym z administracyjnych trybów nadzwyczajnych, co w jeszcze większym stopniu prowadziłoby do mnożenia procesów sądowych i administracyjnych ponad potrzebę.

16 Ustawa z 29 sierpnia 1997 r. - Ordynacja podatkowa, t.jedn.: Dz. U. 2015, poz. 613 ze zm.

17 Ustawa z 14 czerwca 1960 r. - Kodeks postępowania administracyjnego, t.jedn.: Dz. U. 2013, poz. 267 ze zm.

18 Ustawa z 30 sierpnia 2002 r. - Prawo o postępowaniu przed sądami administracyjnymi, t.jedn.: Dz. U. 2012, poz. 270 ze zm. (dalej jako: p.p.s.a.).

19 Tak samo w doktrynie dostrzeżono, że szerokie otwarcie drogi sądowej dla postanowień wydawanych w postępowaniu egzekucyjnym umożliwia przedłużenie tego postępowania w czasie ponad obiektywnie istniejące potrzeby. Zob. J. P. Tarno, Gwarancje procesowe służace zobowiazanemu w egzekucji administracyjnej, „Przegląd Podatkowy” 2009, z. 7, s. 15; R. Hauser, A. Skoczylas, Instytucja zażalenia w postepowaniu egzekucyjnym w administracji, w: J. Supernat (red.), Między tradycja a przyszłościa w nauce prawa administracyjnego. Księga jubileuszowa dedykowana Profesorowi Janowi Bociowi, Wrocław 2009, s. 212-214. 
Za wydaniem takiego postanowienia nie przemawia również wzgląd na istnienie zbliżonej regulacji w k.p.c., która została wprowadzona z powodów czysto praktycznych, w związku z wątpliwościami odnośnie do sposobu orzekania o kosztach postępowania egzekucyjnego $\mathrm{w}$ razie jego zakończenia w inny sposób aniżeli przez umorzenie postępowania ${ }^{20}$. Pomimo tego w doktrynie postępowania cywilnego zauważono, że wprowadzenie regulacji dotyczacej zakończenia postępowania egzekucyjnego kłóci się z charakterystyczną jego cecha, różniąca je od postępowania rozpoznawczego, postępowania klauzulowego oraz postępowania upadłościowego. Ukończenie postępowania egzekucyjnego nie wymaga bowiem wydania specjalnego orzeczenia czy też podjęcia innej czynności decyzyjnej ${ }^{21}$. W doktrynie postępowania cywilnego podobnie jak na gruncie administracyjnego postępowania egzekucyjnego obecny jest pogląd o ściśle wykonawczym charakterze postępowania egzekucyjnego, które nie wymaga podejmowania czynności procesowych zbędnych dla osiagnięcia podstawowego jego celu, którym pozostaje wykonanie obowiązku.

Zakończeniu postępowania przez zaspokojenie wierzyciela bez wydania osobnego aktu procesowego przez organ egzekucyjny nie stoją na przeszkodzie podejmowane przez zobowiązanego czynności zmierzające do obrony przed egzekucja. W orzecznictwie sądowym wskazuje się, że mogą one być dokonywane w trakcie toczącego się postępowania. Z tego powodu za niedopuszczalny uznano wniosek o umorzenie postępowania egzekucyjnego złożony już po jego zakończeniu $^{22}$. Gdy jednak w przepisach u.p.e.a. wyznaczony został termin dokonania określonej czynności, wówczas zakończenie tego postępowania nie stoi na przeszkodzie w jej podjęciu. Przyjęcie przykładowo założenia, że zakończenie postępowania egzekucyjnego wyklucza możliwość złożenia skargi na czynności egzekucyjne, pozbawiałoby zobowiązanego, od którego obowiązek wyegzekwowano, realnej możliwości złożenia skargi na tę czynność egzekucyjna, która do wyegzekwowania takiego obowiązku doprowadziła ${ }^{23}$. Podobnie na organie egzekucyjnym spoczywa obowiązek rozstrzygnięcia wniesionych zarzutów niezależnie od tego, czy pomiędzy ich terminowym wniesieniem a ich rozpatrzeniem dochodzony obowiązek został wykonany ${ }^{24}$.

Ostatecznie rzecz ujmując, nie zawsze wprowadzenie nowej regulacji procesowej sprzyja usprawnieniu biegu danego postępowania. Przerost unormowań tego rodzaju niekiedy wywołuje odmienne skutki od tych, które były zamierzone na wstępie. Przykładem tego jest administracyjne postępowanie egzekucyjne, w którym regulacja procesowa została rozbudowana w zbyt daleko idaccy sposób w porównaniu z celem tego postępowania oraz istniejącego układu jego

20 Art. 816 §3 k.p.c. został dodany do ustawy mocą art. 1 pkt 90 ustawy z 16 września 2011 r. o zmianie ustawy - Kodeks postępowania cywilnego oraz niektórych innych ustaw, Dz. U. 2011, Nr 233, poz. 1381. Wszedł on w życie 3 maja 2012 r. Zob. też uzasadnienie projektu ustawy nowelizującej dostępne na: http://orka.sejm.gov.pl/Druki6ka.nsf/wgdruku/4332 [dostęp: 24.09.2015].

21 J. Jankowski, w: J. Jankowski (red.), K.p.c. Komentarz, t. 2: Art. 730-1088, Warszawa 2013, s. 399-401. Zob. też J. Jankowski, Przebieg postepowania egzekucyjnego, upadłościowego i układowego. Struktura postępowań w ujęciu dynamicznym, Kraków 1999, s. 353-354.

${ }^{22}$ Wyrok NSA z 27 czerwca 2013 r., II FSK 2269/11, CBOSA.

${ }^{23}$ Wyrok NSA z 16 czerwca 2010 r., II FSK 209/09, CBOSA.

${ }^{24}$ Wyrok WSA w Poznaniu z 16 stycznia 2015 r., I SA/Po 731/14, CBOSA; wyrok WSA w Warszawie z 26 maja 2015 r., III SA/Wa 2821/14, CBOSA. 
podmiotów. Wyrazem tego pozostaje choćby liczba zaskarżalnych do sądu administracyjnego postanowień wydawanych na podstawie u.p.e.a. ${ }^{25}$ Ustanowienie obowiązku podjęcia przez organ egzekucyjny kolejnego aktu procesowego pogłębiłoby jedynie rozrost regulacji prawnej przy osiagnięciu nikłych korzyści z perspektywy uprawnień procesowych podmiotów tego postępowania.

Osobnego rozważenia wymagałaby natomiast zasadność wprowadzenia do tytułu wykonawczego takiego zapisu, z którego wynikałoby jasno, czy egzekucja na jego podstawie jest prowadzona, czy też została już zakończona, a jeżeli tak, to w jakim terminie. Tytuł wykonawczy jako najistotniejszy dla bytu administracyjnego postępowania egzekucyjnego dokument urzędowy powinien zawierać wszystkie istotne informacje dotyczące m.in. ram czasowych egzekucji.

\section{Częściowe wykonanie obowiązku}

Problematyka częściowego wykonania obowiązku pozostaje aktualna z punktu widzenia egzekucji obowiązków pieniężnych. W razie egzekucji obowiązku o charakterze niepieniężnym trudno jest wskazać na częściowe jego wykonanie. $\mathrm{Z}$ istoty bowiem powinności tego rodzaju ich realizacja nie może następować etapowo tylko całościowo w tym znaczeniu, że nieuprawnione byłoby traktowanie o procentowym jego wykonaniu ${ }^{26}$.

Częściowa realizacja obowiązku o charakterze pieniężnym nie powoduje sama w sobie zakończenia postępowania egzekucyjnego bez względu na to, czy jest ona rezultatem dobrowolnej wpłaty zobowiązanego, czy też skuteczności działania organu egzekucyjnego i poborcy skarbowego ${ }^{27}$. Egzekucja powinna jednak zostać w takiej sytuacji ograniczona do tej kwoty, która nie została uiszczona przez zobowiązanego czy też nie została wyegzekwowana. Postępowanie egzekucyjne jest wówczas kontynuowane. Częściowe wykonanie obowiązku po wszczęciu postępowania egzekucyjnego nie rodzi konieczności jego umorzenia w tym zakresie, co wynika a contrario z art. $59 \S 1$ pkt 1 u.p.e.a. Trzeba poza tym odróżnić od siebie zakończenie postępowania z powodu realizacji jego celu od zakończenia bez jego osiagnięcia ${ }^{28}$. W doktrynie wskazywane sa jednak takie sytuacje, kiedy to częściowe wykonanie obowiązku powoduje konieczność wydania w tym zakresie postanowienia o umorzeniu postępowania.

Postępowanie egzekucyjne ulega częściowemu umorzeniu, gdy było ono prowadzone na podstawie określonej grupy tytułów wykonawczych i niemożliwe jest wyegzekwowanie należności tylko z części tytułów ${ }^{29}$. Taka sytuacja

${ }^{25}$ R. Hauser i A. Skoczylas wymienili 50 takich postanowień. Zob. eidem, Instytucja zażalenia w postepowaniu egzekucyjnym $w$ administracji, w: J. Supernat (red.), op. cit., s. 212-214.

${ }^{26}$ Specyfikę egzekucji administracyjnej obowiązków niepieniężnych dostrzega J. Olszanowski, zauważając, że egzekucja tego rodzaju ma wymusić na zobowiązanym określonego rodzaju świadczenie, a nie jak w egzekucji obowiązków pieniężnych - zamienić majątek zobowiązanego na pieniądze i wypłacić wierzycielowi należną sumę. Zob. idem, Egzekucja administracyjna obowiazków o charakterze niepieniężnym, Wrocław 2014, s. 26. Zob. też P. Ostojski, Podstawa egzekucji administracyjnej obowiazków niepieniężnych $w$ prawie niemieckim i polskim, „Ruch Prawniczy, Ekonomiczny i Socjologiczny" 74, 2012, z. 4, s. 68-70.

27 Wyrok NSA z 19 października 2012 r., II FSK 492/11, Lex, nr 1227378.

28 Wyrok NSA z 19 października 2012 r., II FSK 492/11, CBOSA.

${ }^{29}$ R. Hauser, Z. Leoński, w: R. Hauser, A. Skoczylas (red.), Postępowanie egzekucyjne w administracji. Komentarz, Warszawa 2014, s. 284. 
dopuszczalna pozostaje także w razie zastosowania art. $59 \S 2$ u.p.e.a. w odniesieniu do części niewyegzekwowanego obowiązku. Przyczyną częściowego umorzenia postępowania egzekucyjnego nie może być jednak częściowe wykonanie obowiązku, ale brak możliwości wyegzekwowania części obowiązku ${ }^{30}$. Częściowe wykonanie obowiązku nie oznacza jego wygaśnięcia w rozumieniu art. $59 \S 1$ pkt 2 u.p.e.a. ${ }^{31}$ Czym innym jest bowiem realizacja obowiazku w trakcie postępowania egzekucyjnego, także w zakresie częściowym, a czym innym wygaśnięcie obowiązku, które nie pociaga za sobą jego wykonania przykładowo z tytułu przedawnienia należności podatkowej. Innymi słowy, wygaśnięcie obowiązku należałoby rozumieć jako utratę jego ważności, która czyni go nieaktualnym z innych powodów, na ogół prawnych, aniżeli wyegzekwowanie od zobowiązanego.

Przyjęcie odmiennego poglądu na temat częściowego umorzenia postępowania egzekucyjnego w razie niepełnego wykonania obowiąku po wszczęciu tego postępowania powodowałoby częstokroć konieczność kilkakrotnego wydawania postanowienia o częściowym umorzeniu postępowania egzekucyjnego, co przekładałoby się na nieefektywność prowadzonego postępowania. Poza tym nie byłoby wiadomo, kiedy i w jakich odstępach czasowych takie postanowienie powinno zostać wydane w razie cyklicznego egzekwowania od zobowiązanego należności pieniężnych czy też dobrowolnej wpłaty z jego inicjatywy.

Okazanie przez zobowiązanego dowodów stwierdzających częściowe wykonanie obowiązku nakłada na organ egzekucyjny zgodnie z art. $45 \S 2$ u.p.e.a. powinność odstapienia od egzekucji ze składnika majątkowego, jeżeli jego wartość znacznie przekracza kwotę ostatecznie dochodzonej należności i zobowiązany ma inne składniki majątkowe, z których egzekucja może być prowadzona. W orzecznictwie sądowym zauważono, że przepis ten służy realizacji zasady stosowania najłagodniejszego środka egzekucyjnego ${ }^{32}$. W takiej sytuacji nie powinno dochodzić do częściowego umorzenia postępowania egzekucyjnego. Postępowanie to należy kontynuować aż do zupełnej realizacji obowiązku z uwzględnieniem wszakże częściowej skuteczności egzekucji w kontekście stosowanych środków egzekucyjnych.

\section{NIEWYKONANIE OBOWIĄZKU}

\section{Nieprzystąpienie do egzekucji}

Administracyjne postępowanie egzekucyjne z różnych przyczyn może zakończyć się brakiem realizacji jego celu w postaci wykonania dochodzonego obowiązu. Przyczyną takiego stanu rzeczy jest niekiedy zaistnienie jednej

${ }^{30}$ P. Pietrasz, w: D. R. Kijowski (red.), U.p.e.a. Komentarz, Warszawa 2015, s. 549.

31 Odmiennie zob. wyrok WSA w Gliwicach z 14 marca 2012 r., I SA/Gl 174/12, CBOSA; wyrok WSA w Gliwicach z 12 kwietnia 2012 r., I SA/Gl 821/11, CBOSA. Por. P. Ostojski, Etapy postepowania przymusowego $w$ administracji względem obowiazków niepieniężnych $w$ prawie Polski i Niemiec, Poznań 2015, s. 258-259.

${ }^{32}$ Wyrok WSA w Bydgoszczy z 30 listopada 2005 r., I SA/Bd 540/05, CBOSA. 
z ujemnych przesłanek obligujących organ egzekucyjny do wydania na podstawie art. $29 \S 2$ u.p.e.a. postanowienia o nieprzystapieniu do egzekucji. $\mathrm{W}$ takim wypadku nie dochodzi w ogóle do wszczęcia egzekucji administracyjnej, a tym samym do zastosowania środków przymusu względem zobowiązanego, zmierzających do wykonania obowiązku.

Podstawami nieprzystapienia do egzekucji są brak podlegania obowiązku wskazanego w tytule wykonawczym realizacji w trybie egzekucji administracyjnej oraz nieprawidłowe wystawienie tytułu wykonawczego w przypadku niespełnienia wymogów, o których stanowi art. 27 § 1 i 2 u.p.e.a. Począwszy od 1 stycznia 2016 r., dzięki nowelizacji art. 29 § 2 u.p.e.a. dokonanej na podstawie art. 39 pkt 9 lit. a ustawy o administracji podatkowej ${ }^{33}$, kolejna przesłanką uzasadniająca nieprzystapienie do egzekucji jest uprawdopodobnienie przez organ egzekucyjny braku uzyskania w toku egzekucji kwoty przewyższającej wydatki egzekucyjne. Jak zostało to wyjaśnione w uzasadnieniu projektu ustawy nowelizującej, dodanie nowej przesłanki braku wszczęcia egzekucji administracyjnej powinno zapobiec podejmowaniu przez naczelników urzędów skarbowych nieefektywnych działań przy jednoczesnym zwiększeniu ich aktywności w innych sprawach, w których możliwe jest osiagnięcie celu egzekucji ${ }^{34}$. Brzmienie nowej przesłanki dopuszczalności egzekucji administracyjnej koresponduje wyraźnie z art. 59 § 2 u.p.e.a., który stanowi o złej kondycji finansowej zobowiązanego w kontekście możliwości umorzenia postępowania egzekucyjnego. $\mathrm{Z}$ tego powodu ustalenia poczynione $\mathrm{w}$ doktrynie ${ }^{35}$ i w orzecznictwie sądowym ${ }^{36}$ na temat przesłanek, o których stanowi art. 59 $\S 2$ u.p.e.a., będą mogły z powodzeniem zostać odniesione do wykładni art. 29 $\S 2$ pkt 2 u.p.e.a. O ile jednak w ostatnim ze wskazanych przepisów ustawodawca stanowi o uprawdopodobnieniu braku uzyskania od zobowiąanego kwoty przewyższającej wydatki egzekucyjne, o tyle w przypadku art. $59 \S 2$ u.p.e.a. konieczne jest stwierdzenie tej okoliczności przez organ egzekucyjny.

$\mathrm{Z}$ wprowadzeniem tej zmiany połaczone zostało dodanie do art. 29 u.p.e.a. nowego § 2a, w którym wydanie postanowienia o nieprzystapieniu do egzekucji zostało uzależnione od złożenia przez wierzyciela w terminie 14 dni, począwszy od dnia doręczenia przez organ egzekucyjny zawiadomienia o przyczynach nieprzystapienia do egzekucji osobnego wniosku w tym przedmiocie. Z uzasadnienia projektu ustawy nowelizującej wynika, że w ten sposób wierzyciel uzyska dodatkową możliwość szybszej reakcji na popełnione uchybienia w sporządzonym tytule wykonawczym ${ }^{37}$. Wprowadzona zmiana powinna usprawnić przebieg postępowania egzekucyjnego, zmierzając do szybszego wszczęcia egzekucji bądź też jej zaniechania w razie trwałego i nieusuwalnego charakteru zaist-

${ }^{33}$ Ustawa z 10 lipca 2015 r. o administracji podatkowej, Dz. U. 2015, poz. 1269.

${ }_{34}$ Zob. uzasadnienie projektu ustawy o administracji podatkowej, http://www.sejm.gov.pl/ Sejm7.nsf/druk.xsp?nr=3320 [dostęp: 24.09.2015].

${ }^{35}$ R. Hauser, Z. Leoński, w: R. Hauser, A. Skoczylas (red.), U.p.e.a. Komentarz, Warszawa 2014, s. 285-286; P. Pietrasz, w: D. R. Kijowski (red.), U.p.e.a. Komentarz, Warszawa 2015, s. 576578.

${ }^{36}$ Wyrok NSA z 25 lutego 2014 r., II FSK 687/12, CBOSA; wyrok NSA z 27 maja 2015 r., II FSK 1469/13, CBOSA.

${ }^{37}$ Zob. uzasadnienie projektu ustawy o administracji podatkowej: http://www.sejm.gov.pl/ Sejm7.nsf/druk.xsp?nr=3320 [dostęp: 24.09.2015]. 
niałych przeszkód. Podobnie w przypadku przesłanki dotyczącej braku prawdopodobieństwa uzyskania $\mathrm{w}$ toku egzekucji kwoty przewyższającej wydatki egzekucyjne, nowe brzmienie art. $29 \S 2$ i 2 a u.p.e.a. umożliwi wierzycielowi podjęcie próby obrony przed odmowa przystapienia przez organ egzekucyjny do drugiego etapu postępowania w postaci stadium egzekucji. W przypadku braku porozumienia pomiędzy organem egzekucyjnym i wierzycielem, drugi z wymienionych podmiotów będzie mógł domagać się wydania zaskarżalnego zażaleniem postanowienia o nieprzystapieniu do egzekucji.

Nowelizacja art. $29 \S 2$ u.p.e.a. oraz dodanie do tego przepisu nowego $\S 2 \mathrm{a}$ sa istotnymi argumentami na rzecz stanowiska o braku możliwości odpowiedniego stosowania na gruncie u.p.e.a. art. $64 \S 2$ k.p.a. ${ }^{38} \mathrm{~W}$ przepisach tych przewidziany został odrębny tryb relacji procesowych występujących pomiędzy organem egzekucyjnym i wierzycielem w przypadku nieprawidłowego wystawienia przez wierzyciela tytułu wykonawczego. Organ egzekucyjny, zawiadamiając wierzyciela o przyczynach nieprzystapienia do egzekucji, nie wzywa tego podmiotu do usunięcia braków w siedmiodniowym terminie ani nie formułuje rygoru $\mathrm{w}$ postaci pozostawienia wniosku o wszczęcie egzekucji bez rozpoznania. Postanowienie o nieprzystapieniu do egzekucji wydawane jest tylko na wniosek wierzyciela w terminie 14 dni od doręczenia wyżej wskazanego zawiadomienia. Dokonana zmiana zasługuje na aprobatę także z tego względu, że jest ona wyrazem odformalizowania w nieznacznym stopniu przebiegu postępowania egzekucyjnego, które przy braku wniosku ze strony wierzyciela może zakończyć się jedynie pisemnym powiadomieniem o przyczynach nieprzystapienia do egzekucji.

\section{Umorzenie postępowania egzekucyjnego}

Zakończenie administracyjnego postępowania egzekucyjnego może nastapić przez jego umorzenie, które w równym stopniu dotyczy obowiązków o charakterze pieniężnym, jak i niepieniężnym ${ }^{39}$. Polega ono na przerwaniu toku postępowania, uchyleniu dokonanych czynności egzekucyjnych oraz podjęciu rozstrzygnięcia o zaniechaniu dalszego prowadzenia postępowania, gdy wykonanie egzekwowanego obowiązku staje się niedopuszczalne albo niemożliwe. Organ egzekucyjny obowiązany jest umorzyć prowadzone postępowanie w razie zaistnienia jednej z podstaw, o których stanowi art. 59 § 1-2 u.p.e.a. ${ }^{40}$ Każda $\mathrm{z}$ tych podstaw stanowi przeszkodę uniemożliwiającą dalszą kontynuację tego postępowania.

38 J. Wyporska-Frankiewicz, w: red. J. P. Tarno, Doradca podatkowy w egzekucji administracyjnej należności pieniężnych, Warszawa 2011, s. 84; A. Skoczylas, w: R. Hauser, Z. Niewiadomski, A. Wróbel (red.), System prawa administracyjnego, t. 9, s. 325. Odmiennie zob. B. Adamiak, w: B. Adamiak, J. Borkowski, Postępowanie administracyjne $i$ sqdowoadministracyjne, Warszawa 2010 , s. 550 .

${ }^{39}$ M. Masternak, w: T. Jędrzejewski, M. Masternak, P. Rączka, Administracyjne postępowanie egzekucyjne, Toruń 2013, s. 127. Odmiennie zob. L. Klat-Wertelecka, Niedopuszczalność egzekucji administracyjnej, Wrocław 2009, s. 234.

${ }^{40}$ Umorzenie postępowania egzekucyjnego następuje także w szczególnych przypadkach przewidzianych w u.p.e.a. oraz w innych ustawach. Szerzej zob. M. Masternak, w: T. Jędrzejewski, M. Masternak, P. Rączka, Administracyjne postępowanie egzekucyjne, Toruń 2013, s. 128. 
Jak jednak przyjmuje się w doktrynie, trwały charakter przeszkód obligujących organ egzekucyjny do umorzenia prowadzonego postępowania może być nieprzemijajacy, materialny bądź też odnosić się jedynie do formy konkretnie prowadzonego postępowania ${ }^{41}$. W drugim ze wskazanych przypadków usunięcie przeszkody po zakończeniu postępowania, w którym ona powstała, umożliwia powtórne jego wszczęcie i w efekcie tego wykonanie tego samego obowiązku.

Odmiennie aniżeli w sytuacji wyegzekwowania obowiązku, umorzenie postępowania przybiera procesową postać postanowienia wydawanego na podstawie art. $59 \S 3 \mathrm{w} z w . \mathrm{z} \S 4$ u.p.e.a. Na postanowienie w sprawie umorzenia postępowania egzekucyjnego stosownie do art. $59 \S 5$ p.p.s.a. przysługuje zażalenie zarówno zobowiązanemu, jak i wierzycielowi niebędącemu organem egzekucyjnym. Konsekwencja tego jest objęcie z mocy art. $3 \S 2$ pkt 3 p.p.s.a. rozstrzygnięcia zapadłego na skutek rozpatrzenia przez organ wyższego stopnia tego postanowienia kontrolą sądu administracyjnego.

Jak zostało to wyjaśnione w orzecznictwie sąowym, ostateczne postanowienie o umorzeniu postępowania egzekucyjnego nie oznacza wszakże, że na zobowiązanym przestał ciążyć obowiązek, którego wykonanie było przedmiotem umorzonego postępowania. Nie można jemu również przypisywać waloru cechy powagi rzeczy osądzonej, ponieważ organ egzekucyjny nie jest uprawniony do badania zasadności i wymagalności obowiązku objętego tytułem wykonawczym, co wynika z art. $29 \S 1$ u.p.e.a. ${ }^{42}$ Ze stanowiska tego uprawnionym pozostaje wyprowadzenie dalej idącego wniosku na temat braku konieczności wydawania osobnego postanowienia o zakończeniu administracyjnego postępowania egzekucyjnego. Postanowienie takie nie powodowałoby utraty mocy prawnej decyzji czy też innego aktu, na którego podstawie prowadzona była egzekucja. Nie mogłoby ono stanać na przeszkodzie ponownemu wszczęciu postępowania egzekucyjnego w razie zaistnienia takich okoliczności, które świadczyłyby o braku całkowitego wykonania obowiązku. Z racji na ściśle wykonawczy charakter postępowania egzekucyjnego wydanie analizowanego postanowienia nie prowadziłoby do przyznania zobowiązanemu dodatkowych uprawnień materialnoprawnych, które mogłyby zostać objęte jego mocą wiążąca, w stosunku do wykonanego obowiązku.

\section{PODSUMOWANIE}

Administracyjne postępowanie egzekucyjne może zakończyć się w różnoraki sposób, zarówno przez wykonanie egzekwowanego obowiązku, jak i jego brak. W pierwszym przypadku postępowanie to kończy się aktem realnym w postaci ostatniej czynności egzekucyjnej zmierzającej do wykonania obo-

41 A. Skoczylas, w: R. Hauser, Z. Niewiadomski, A. Wróbel (red.), System prawa administracyjnego, t. 9, s. 328-329; P. Pietrasz, w: D.R. Kijowski (red.), U.p.e.a. Komentarz, Warszawa 2015 , s. 546 .

42 Wyrok NSA z 17 października 2006 r., I OSK 804/06, CBOSA; wyrok NSA z 21 listopada 2012 r., II FSK 710/11, CBOSA. 
wiązku objętego tytułem wykonawczym. W drugiej sytuacji organ egzekucyjny wydaje postanowienie bądź to o nieprzystapieniu do egzekucji, bądź o umorzeniu postępowania egzekucyjnego. Od rozstrzygnięć tych przysługuje zażalenie, a tym samym skarga do sądu administracyjnego.

Różnica w odmiennym uregulowaniu przez ustawodawcę różnych sposobów zakończenia postępowania egzekucyjnego wynika z konsekwencji łączących się z ich wystapieniem. O ile w przypadku braku realizacji egzekwowanego obowiązk koniecznym pozostaje autorytatywne przesądzenie zaistnienia przeszkody uniemożliwiającej dalszą kontynuację postępowania, o tyle w razie pozytywnego zakończenia postępowania egzekucyjnego nie istnieje potrzeba potwierdzenia tego stanu faktycznego jakimkolwiek aktem procesowym. Zobowiązany ma wówczas do dyspozycji takie instrumenty prawne, które w sposób efektywny umożliwia podjęcie obrony przed ewentualnymi dalszymi działaniami polegajacymi na dalszym prowadzeniu postępowania egzekucyjnego pomimo realizacji obowiązku. Należą do nich prawo do wniesienia zarzutu, żądania odstapienia od czynności egzekucyjnych oraz powództwa przeciwegzekucyjnego.

Zbędnemu formalizowaniu zakończenia postępowania egzekucyjnego stoi na przeszkodzie wzgląd na sam jego charakter prawny. W postępowaniu tym nie zapada jakakolwiek decyzja, która miałaby wpływ na ukształtowanie praw i obowiązków uczestniczących w nim podmiotów. Z tego względu ściśle proceduralne oraz $\mathrm{w}$ istocie swojej wykonawcze rozstrzygnięcia zapadające $\mathrm{w}$ tym postępowaniu nie korzystają $\mathrm{z}$ atrybutu powagi rzeczy osądzonej. O ile w cywilnym procesie egzekucyjnym konieczność stwierdzenia przez komornika w drodze postanowienia o zakończeniu postępowania egzekucyjnego wynika z konieczności podjęcia rozstrzygnięcia co do kosztów, o tyle w administracyjnym postępowaniu egzekucyjnym problem ten nie jest na tyle doniosły. W u.p.e.a. zarówno powstanie, jak i rozliczenie kosztów dokonywane jest w odmienny sposób aniżeli w k.p.c. W przypadku opłat egzekucyjnych będących w praktyce głównym składnikiem kosztów, powstają one z mocy art. $64 \S 1$ i art. 64a $\S 1$ u.p.e.a. wraz z podjęciem konkretnych czynności egzekucyjnych. Zarówno sposób obliczenia, jak i poboru kosztów określony został w u.p.e.a. Samo postanowienie w przedmiocie kosztów może zostać wydane dopiero po zakończeniu postępowania egzekucyjnego.

W przeprowadzonych rozważaniach wspomniano o konieczności dążenia do uzyskania równowagi pomiędzy podejmowanymi w trakcie postępowania egzekucyjnego czynnościami procesowymi oraz czynnościami faktycznymi, zmierzającymi bezpośrednio do realizacji obowiązku. W aktualnym stanie prawnym równowaga ta nie jest zachowana z powodu zbyt dużego nasycenia tego postępowania elementami procesowymi, czego wyrazem pozostaje objęcie sądową kontrola ponad pięćdziesięciu postanowień podejmowanych na podstawie u.p.e.a. Ustanowienie osobnej regulacji procesowej dotyczącej zakończenia administracyjnego postępowania egzekucyjnego tylko pogłębiłoby obecny stan rzeczy.

dr hab. Wojciech Piatek

Uniwersytet im. Adama Mickiewicza w Poznaniu

wojciech.piatek@amu.edu.pl 


\section{COMPLETION OF AN ADMINISTRATIVE ENFORCEMENT PROCEDURE}

\section{Sum mary}

The article tackles the issue of the different ways in which administrative enforcement proceedings may end. The characteristic feature of this proceeding is the lack of a separate regulation in the event of a total performance of the obligation. Such a legal situation has been examined, taking into account on the one hand, the protection of the rights of the obliged person, and on the other hand, the nature and effectiveness of enforcement proceedings. The legal nature of these proceedings requires a special role of the actual actions being taken. Thus legal actions must be undertaken in strict subordination of achieving the goal of this proceeding, this goal being performance of the obligation imposed on the obliged person. 
